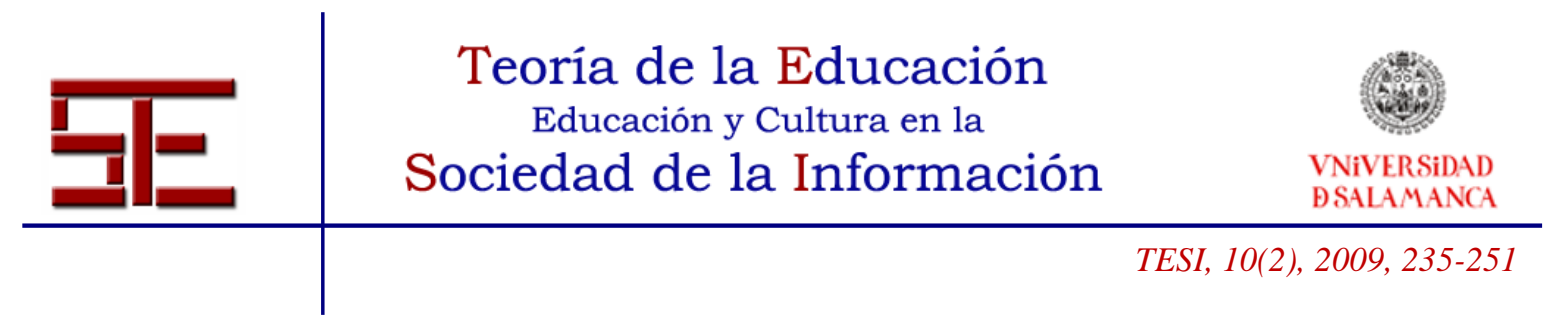

\title{
TECNOLOGÍAS DE LA INFORMACIÓN Y LA COMUNICACIÓN PARA EL DESARROLLO: EJEMPLOS EN INDIA Y UGANDA
}

Resumen: Las Tecnologías de la Información y de la Comunicación (TIC) se relacionan con los usos que las personas hacen de las tecnologías que en un determinado momento están disponibles, dentro de ciertos contextos institucionales, económicos, sociales y culturales. Este artículo se centra en el análisis de las aplicaciones TIC para el desarrollo social y económico, y presenta y discute algunos proyectos y debates del proceso de las TIC para el desarrollo (ICT4D). Sugiere que es necesaria una segunda revolución digital, en la cual los contenidos y formas creativas de utilizar la tecnología tengan efectos socioeconómicos positivos en las poblaciones más desfavorecidas. Muchas de las historias de éxito ilustran que los principales desafíos no residen en la tecnología en sí misma, sino en la organización, coordinación y establecimiento de un ambiente creativo y motivador entre los variados actores implicados.

Palabras clave: Tecnologías de la Información y Comunicación para el Desarrollo (ICT4D); Segunda Revolución Digital.

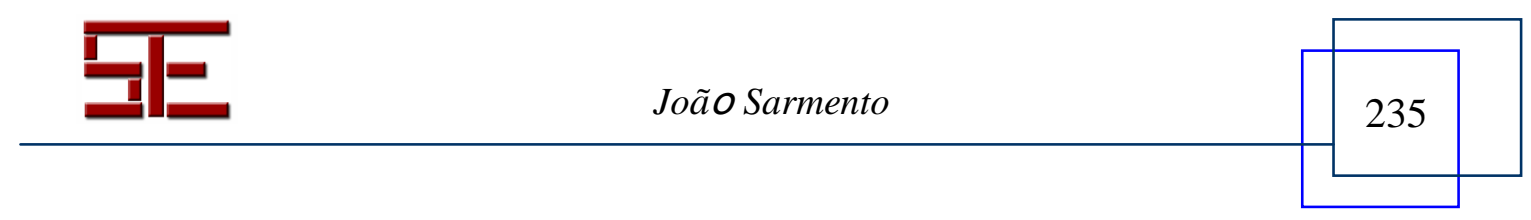




\section{TECNOLOGIAS DE INFORMAÇÃO PARA O DESENVOLVIMENTO: CASOS EN INDIA AND UGANDA1}

Resumo: As Tecnologias de Informação e Comunicação (TICs) são aqui entendidas como principalmente relacionadas com os usos que as pessoas dão às tecnologias que num determinado momento estão disponíveis, dentro de certos contextos institucionais, económicos, sociais e culturais. Este artigo centra-se nas aplicações das TICs no desenvolvimento social e económico, e apresenta e discute alguns projectos e debates do proceso das TICs para o desenvolvimento (ICT4D). Sugere-se que é necessária uma segunda revolução digital, na qual os conteúdos e formas criativas de utilizar a tecnología têm efeitos socioeconómicos positivos nas populações mais favorecidas. Muitas das histórias de sucesso ilustram que os principais desafios não residem na tecnologia em si mesma, mas na organização, coordenação e estabelecimento de um ambiente criativo e motivante entre os vários actores implicados.

Palavras-chave: Tecnologias de Informação e Comunicação para o Desenvolvimento (ICT4D); Segunda Revolução Digital; Empossar.

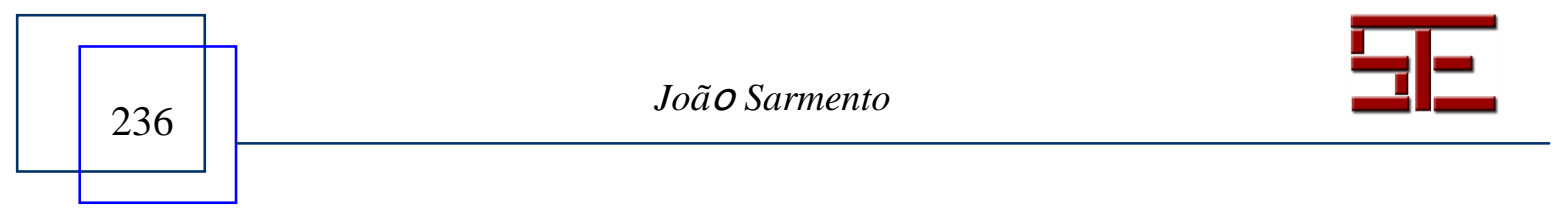




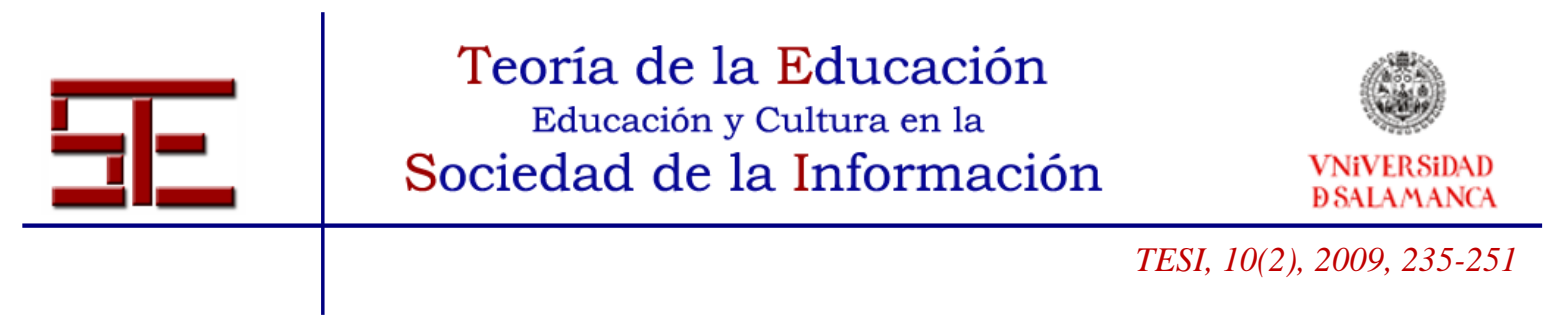

\section{INFORMATION AND COMMUNICATION TECHNOLOGIES FOR DEVELOPMENT: EXAMPLES FROM INDIA AND UGANDA}

Abstract: Information and Communication Technologies (ICTs) are here understood as principally related to the uses that people give to the technologies which are available at a certain moment and within certain institutional, economic, social and cultural contexts. This article focuses on ICTs and their applications in the field of social and economic development, and presents and discusses some engagements and debates in the process of ICT for Development (ICT4D). It is argued that a second digital revolution in needed, in which contents and creative ways of using technology have positive socioeconomic impacts for marginalised people. Many of the existing success stories illustrate that the main challenges are not actually in the technology itself, but in the organisation, coordination and establishment of a motivational and creative environment among various stakeholders and people.

Keywords: Information and Communication Technologies for Development (ICT4D); Second Digital Revolution; Empowerment.

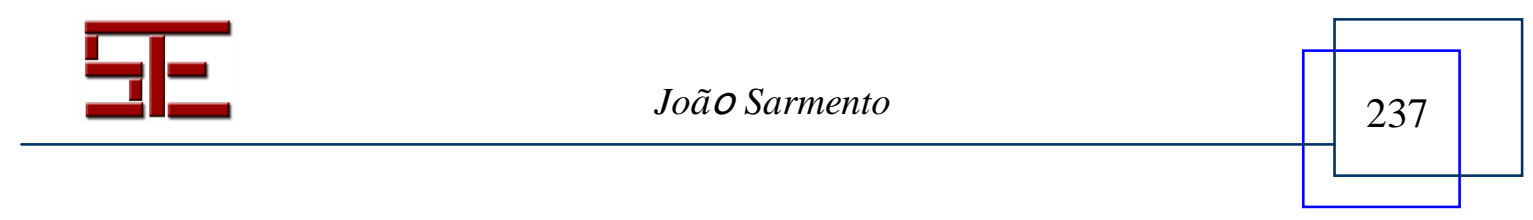




\begin{tabular}{c|c} 
Teoría de la Educación \\
Educación y Cultura en la \\
$\begin{array}{l}\text { VNiVERSIDAD } \\
\text { DSALAMANCA }\end{array}$ \\
\hline TESI, 10(2), 2009, pp. 235-251
\end{tabular}

\title{
INFORMATION AND COMMUNICATION TECHNOLOGIES FOR DEVELOPMENT: EXAMPLES FROM INDIA AND UGANDA
}

\author{
João Sarmento \\ j.sarmento@geografia.uminho.pt \\ Geography Department, University of Minho \\ Guimarães, Portugal. \\ Centre for Geographical Studies, Lisbon.
}

\section{1.- ICT4D}

There are many definitions of Information and Communication Technologies (ICTs): from 'tools that people use to share, distribute, and collect information and to communicate with one another, one-on-one, or in groups, through the use of computers and interconnected computer networks' (United Nations, 2005), to 'hardware, software, networks, and media for collection, storage, processing, transmission, and presentation of information' (World Bank, 2002). My understanding is that ICTs are not so much about the computer, the Internet, modems and telephone lines. They are principally about information and communication, and above all about the uses that people give to the technologies which are available at a certain moment and within certain institutional, economic, social and cultural contexts. If the information society is really going to create a global village as envisioned by Marshall McLuhan, a digital agora, or a virtual community as argued by Howard Rheingold, ICTs access, usage and economic and social benefits in developing countries has to be assured, because communities and democracy are inclusive and participatory rather than exclusive and segmented. In this context, as we try to use new technologies for community development and alleviation of poverty2, contents and uses are of paramount importance. This article focuses on ICTs and their applications in the field of social and economic development, and presents and discusses some engagements and debates in the process of ICT for Development (ICT4D). Overall, it is argued that a second digital revolution in needed, in which contents and creative ways of using technology have positive socioeconomic impacts for marginalized people.

\section{2.- THE FIRST DIGITAL REVOLUTION AND THE DIGITAL DIVIDE}

The First Digital Revolution, characterised by a mass digitization of data, had a number of important consequences for culture, society, economy and spatial relations

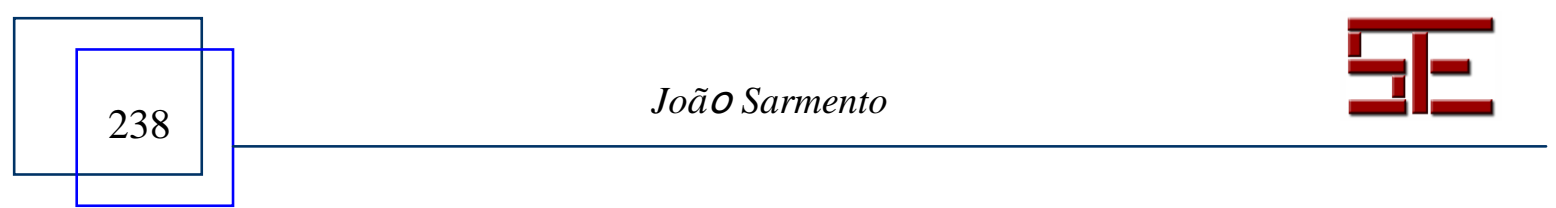




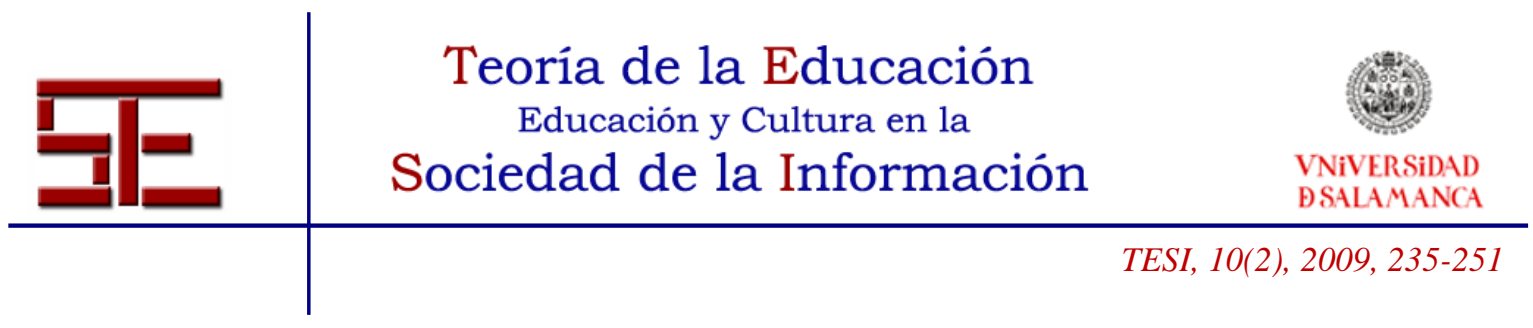

throughout the 1980s and 1990s. It changed the way people think, behave, communicate, work and earn their livelihood; it forged new ways to create knowledge, educate people and disseminate information; it restructured the way the world conducts economic and business practices, runs governments and engages politically; it opened the possibility for the speedy delivery of humanitarian aid and healthcare; it provided a new vision for environmental protection and; it created new avenues for entertainment and leisure (see Beck 2007; Castells 1996-98; Negroponte 1995; Sarmento, 2004). Castells (2002) refers to the period of 1997-2002 as the peak period of Information Technology growth in most industrialized nations, which was rapidly followed by the end of the first Digital Revolution, symbolised by Silicon Valley's dot-com bust, which poured trillions of dollars into the global economy, and generated very high unemployment rates. Silicon Valley was quickly metamorphosed into Death Valley.

In a perfect world, digital opportunity would mean everybody having easy access to ICTs at affordable prices; all homes equipped with ICT devices; all citizens having mobile ICT devices; and everyone using broadband. This is far from being the case in Western countries and clearly very far from the situation in developing countries, where access to ICT has heavy costs. Kofi Annan (2002) referred to the Digital Divide as 'the new information and communications technologies are among the driving forces of globalisation. They are bringing people together, and bringing decision makers unprecedented new tools for development. At the same time, however, the gap between information 'haves' and 'have-nots' is widening, and there is a real danger that the world's poor will be excluded from the emerging knowledge-based global economy'.

Statistical data also illustrates that almost all African countries with very low Internet access are among the least developed countries in the world in terms of health, education, and income. This indicates that there seems to be a connection between global social gaps and the global digital divide. In this context, the United Nations defends that 'the network society is creating parallel communications systems: one for those with income, education and literally connections, giving plentiful information at low cost and high speed; the other for those without connections, blocked by high barriers of time, cost and uncertainty and dependent upon outdated information' (UNDP, 1999: 63). Although the information revolution is changing the world, its impacts are felt in many different ways across the globe. Yet, the digital divide is not a new problem. Older technical divides that can be traced back to previous experiences in fields like economic development and sustainable development.

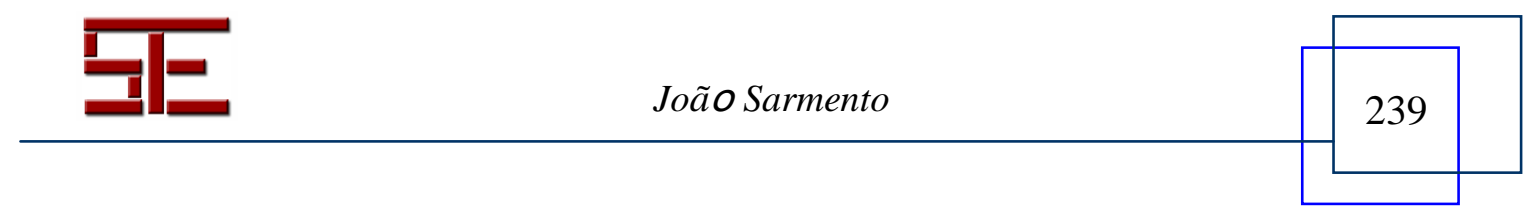




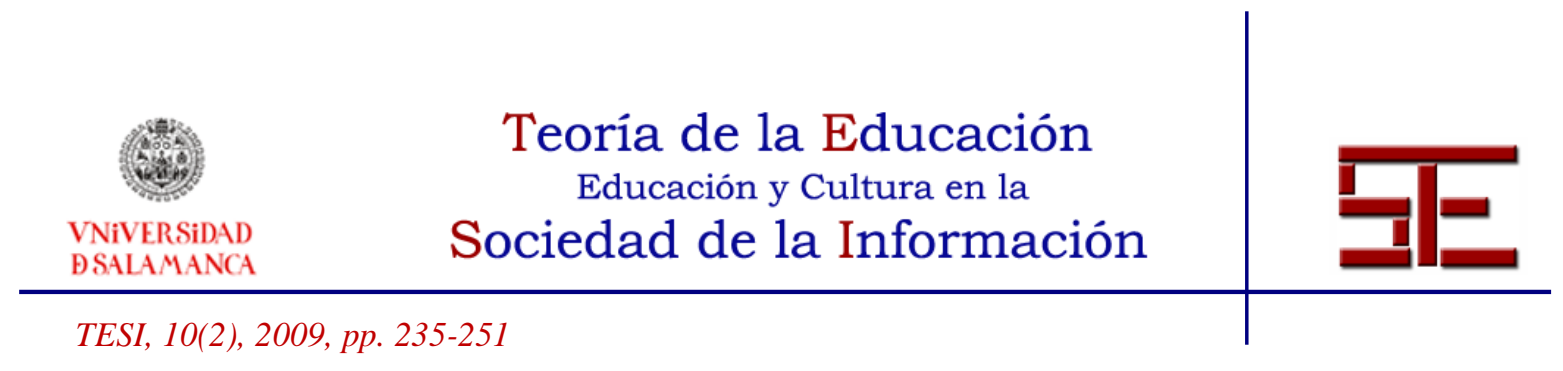

Castells (2002: 248) argues that access is 'a requisite for overcoming inequality in a society in which dominant functions and social groups are increasingly organized around the Internet'. The same line of argument is followed by Jan van Dijk (2006: 178), who defines the digital divide as 'the gap between those who do and do not have access to computers and the Internet'. Nonetheless, access alone does not solve things; the actual problem about the digital divide is very complex. It concerns both insufficient access to computers and lack of technical know-how, but also underlying social issues such as poverty, literacy, and the fact that most people do not see how the communication and the technologies could be relevant to their lives. Thus, Van Dijk and Hacker (2003) argue that there are four types of barriers to access: (i) the lack of 'mental access', i.e., the lack of elementary digital experience; (ii) the lack of 'material access', meaning a lack of possession of computers and network connections; (iii) the lack of 'skill access', which is a lack of digital skills; and finally (iv) the lack of 'usage access', denoting the lack of meaningful usage opportunities. The existence of different types of barriers and not only a question of access is evident through the research of Van Dijk (2006), which illustrates that people with high levels of education and income tend to use database, spreadsheet, bookkeeping, and presentation applications significantly more than people with low levels of education and income who favour simple consultations, games, and other entertainment. Mental and material access is not enough (Van Dijk and Hacker, 2003), but faith in bridging the digital gap in this way is widespread in science.

Figure 1 Private Cybercafé in Tarrafal, Cape Verde

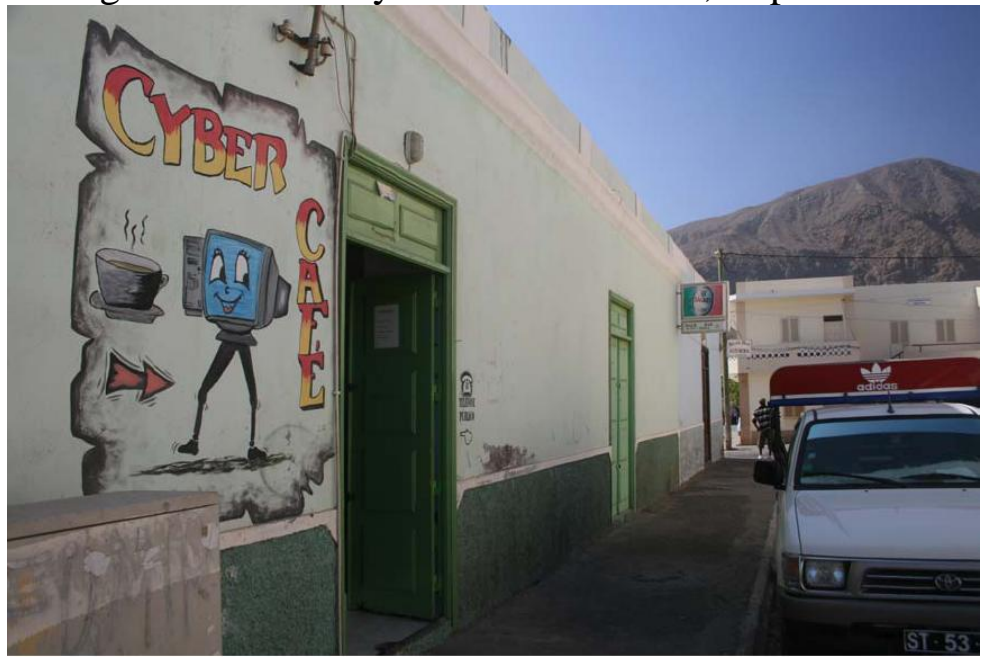

Source: Author, April 2008

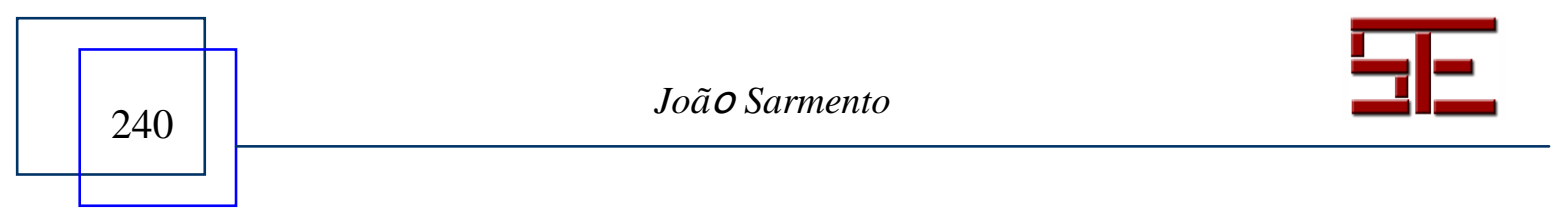




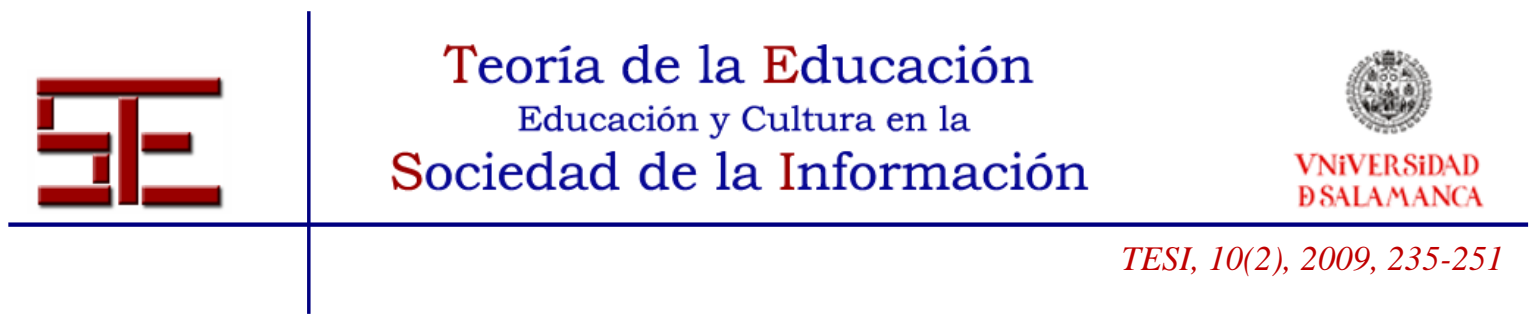

Furthermore, the view that ICTs are usually understood to refer to computers and the Internet is quite limited, as it excludes the more traditional and usually more common technologies such as radio, television, telephones, public address systems, and even newspapers, which also carry information. In particular, the potential value of radio and more recently of mobile phones as sources of development information should not be overlooked, especially in view of their almost ubiquitous presence in developing countries, including the rural locations in which the vast majority of the poor live (see below the example of Veerampatinam).

\section{3.- THE SECOND DIGITAL REVOLUTION: EMPOWERING PEOPLE}

Between the years 2000 and 2004 hundreds conferences and thousands of sessions on regular conferences have been dedicated to the theme of the 'digital divide'. Yet, in the years 2004 and 2005 attention started to decline (Van Dyke, 2006). It is not new to study the present reality that computers and the Internet mean nothing for billions of poor people. Yet, in a growing number of instances, and as part of a quieter revolution, a variety of local organizations, aid agencies and government bodies are discovering that ICTs can be used to extend the reach of the information revolution to the poorest of people living in the remotest corners of the world. That process and set of initiatives, being from International Organisations such as the UN, UNESCO or the World Bank, Governments, or Non Government Organisations (NGOs), are part of what some name the Second Digital Revolution.

Since the digital divide is the result rather than the cause of poverty, and efforts to bridge it must be embedded within effective strategies that address the causes of poverty, it is important to reconsider the aims of the Millennium Goals, which set clear targets for reducing poverty, hunger, disease, illiteracy, environmental degradation, and discrimination against women by 2015 , on the basis of the global situation during the 1990s (UN, 2006)3. Furthermore, earlier patterns of adoption and diffusion of technology suggest that ICTs will not achieve their full potential without suitable attention being paid to the wider processes in which they are intended to assist and to the context within which they are being implemented.

The International Telecommunication Union, following a proposal by the Government of Tunisia, resolved at its Plenipotentiary Conference in Minneapolis in 1998 to hold a World Summit on the Information Society (WSIS) and place it on the agenda of the United Nations. This initiative, sponsored by the United Nations, took place for the first

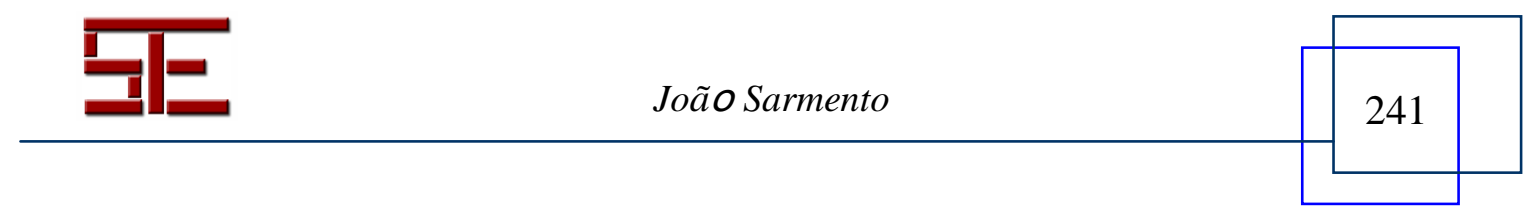




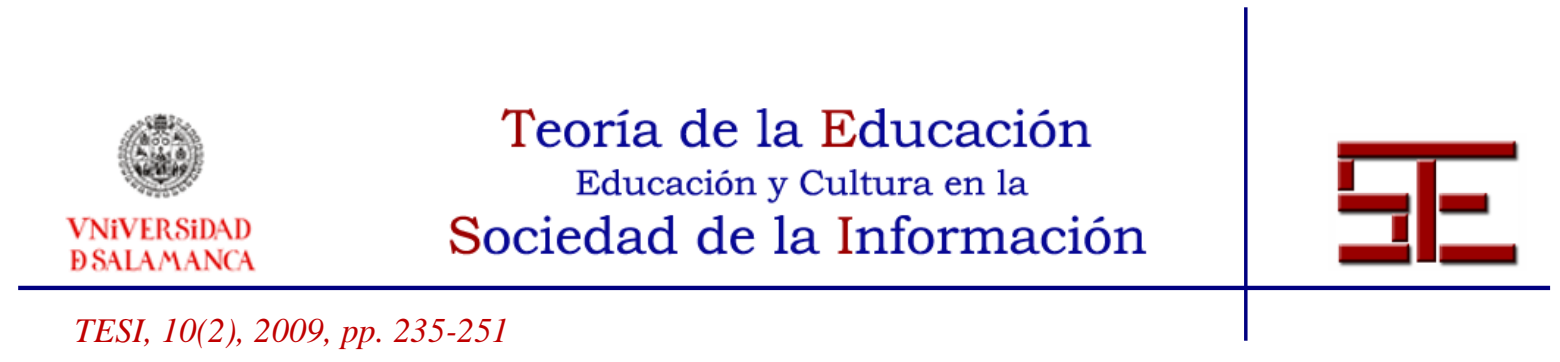

time in Geneva, Switzerland, in 2003 (10-12 December)4, and then in Tunis, Tunisia, in 2005 (16-18 November). The Geneva Phase resulted in the adoption of the Geneva Declaration of Principles and Geneva Plan of Action; The Tunis Phase resulted in the adoption of the Tunis Commitment and the Tunis Agenda for the Information Society. The four outcome documents of the Summit challenge the world community to build an Information Society that is 'people-centred, inclusive and development-oriented' and where 'everyone can create, access, utilize and share information and knowledge' (ITU, 2006). One further challenge that is outlined concerns the commitment to turn the 'digital divide into a digital opportunity for all', and to provide access to ICT infrastructure and services that is 'universal, ubiquitous, equitable and affordable'(ITU, 2006).

The very broad objectives, goals and targets that came out of the meeting were to establish community access points, connect ICTs with villages, education establishments (universities colleges, secondary schools and primary schools), scientific and research centres; public libraries, cultural centres, museums, post offices and archives, health centres and hospitals local and central government departments, establish websites and email addresses; adapt all primary and secondary school curricula to meet the challenges of the Information Society, taking into account national circumstances; ensure that all of the world's population have access to television and radio services; encourage the development of content; put in place technical conditions in order to facilitate the presence and use of all world languages on the Internet; and ensure that more than half the world's inhabitants have access to ICTs within their reach. Despite the creation of the Digital Solidarity Fund (DSF) 5 in Geneva, several problems and much uncertainty remains as to how to fund the actions of the plans established in Geneva and Tunis. There are concerns by some donors over the creation of another 'Global Fund', and the private sector and civil society are seeking substantial external inputs.

The existent experience of attempting to integrate ICTs into Development Co-operation can provide valuable knowledge to the planning of future projects. The Canadian International Development Agency (CIDA) stresses the need for projects to be locally owned and accompanied by human capacity development in order to be sustainable.

The United States Agency for International Development (USAID) emphasises the fact that for the majority of donors the main constraint in effectively using ICT for development is not equipment capacity. Again CIDA highlights the importance of equal access to ICT that various social groups must have, particularly disadvantaged groups

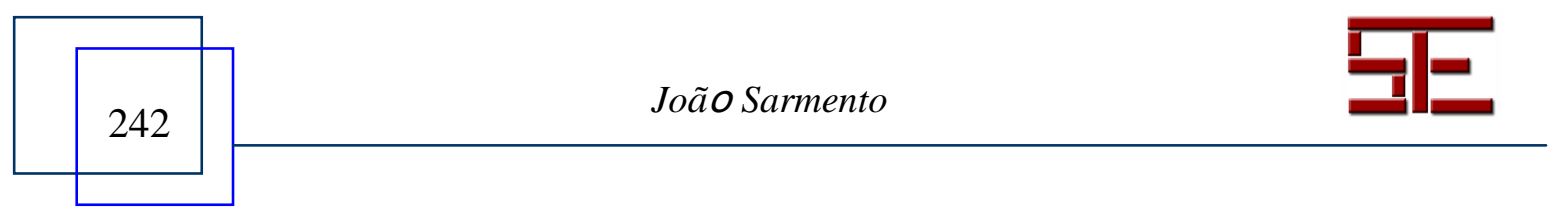




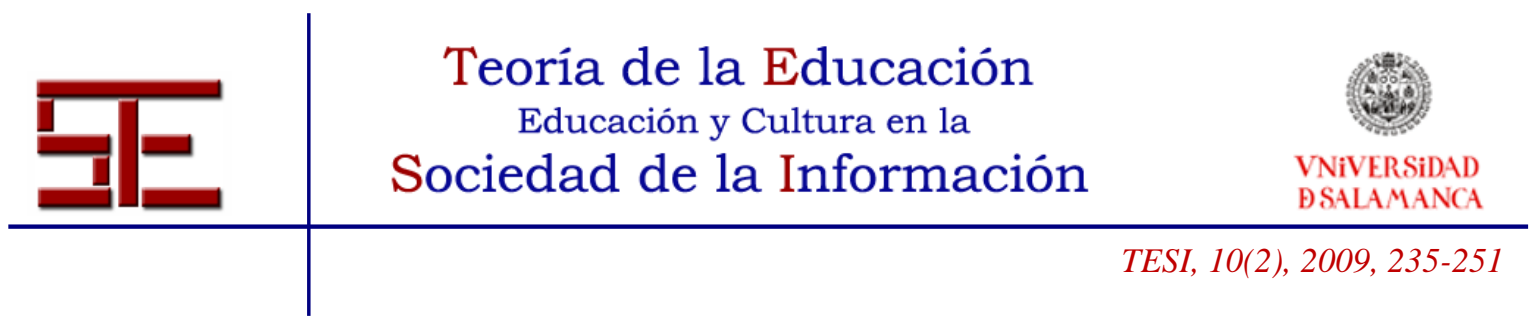

such as the poor, children, and indigenous people, in order to achieve positive development impacts. Finally, the World Bank recommends that because many important aspects of information and communication infrastructures are cross-border in nature, there is a need for international/regional co-operation.

\section{4.- GLOBAL INFORMATION, TECHNOLOGY AND DEVELOPMENT}

Access to information and the construction of knowledge at a global scale are very uneven processes, and ICTs play a critical role. Let me discuss the examples of the importance of Free Open Source Software (FOSS), the Digitalisation of information and control of contents, and the Transferring of Technology, to address this issue. Open source software has been realized mainly within projects such as the Linux operating system. According to the Free Software Foundation (1996), open source software or free software is software that provides four kinds of freedom for the user: the freedom to run the program, for any purpose; the freedom to study how the program works, and adapt it to specific needs (access to the source code is a pre-condition for this); the freedom to re distribute copies so that someone can help his neighbour; the freedom to improve the program, and release these improvements to the public, so that the whole community benefits (again access to the source code is a pre-condition for this). Proprietary software and its associated costs is a barrier to ICT adoption, as well as the real costs associated with hardware and software upgrades and maintenance. In recent years there has been an increasing debate on the role and potential benefits of FOSS, particularly in supporting developing countries in their attempts to increase the use of ICT (Bridges.org, 2005). The central issue relates to how FOSS can be integrated into strategies for social and economic development.

Another relevant issue concerns the Digitalisation of information about the developing world. According to Limb (2006), scholars and their institutions in the North are benefitting and will increasingly benefit from better access to digitized data about Africa, whereas scholars in Africa are unlikely, at least in the short term, to enjoy anything near similar. Yet, there are modest signs that Pan-African organisations are themselves starting the process of digitising the continent, and the challenge in the future could be the fairness of access to and sharing of this information, and the sustainability of processes and results. Connected to the still uneven global access of information, is the substantial controversy emerging from the World Bank initiative 'Global Development Gateway', which relates to contents. This World Bank initiative, a 'knowledge bank' directed by the Development Gateway Foundation, a public-private

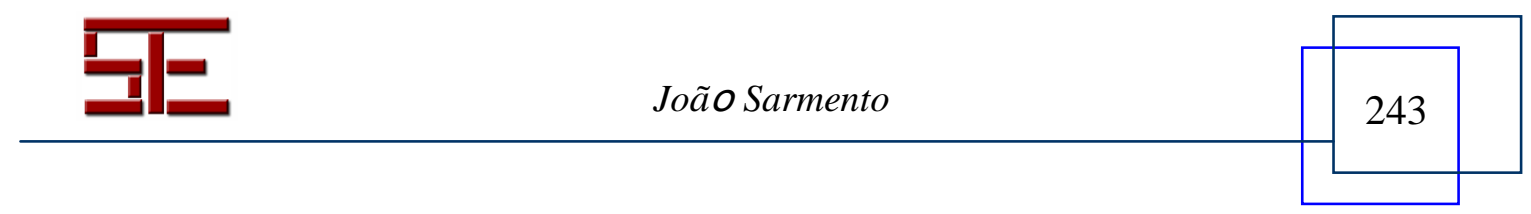




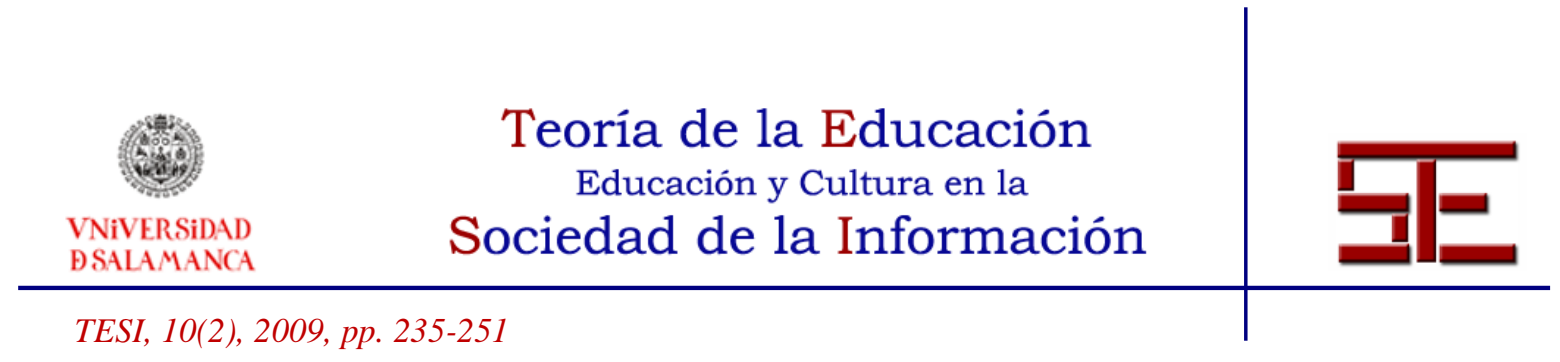

partnership where the board of directors represents civil society and public and private donors, is associated to the idea of establishing an interactive portal for information on sustainable development and poverty reduction. This project is expected to promote government quality and efficiency by providing information on best practices, networks for sharing solutions and experiences, and tools for analysis and problem-solving. The existing controversy revolves around the construction of a 'super-site' and a gatekeeper on development information, in which management and control might not be impartial and beneficial to all, at the same time as output may tend to reflect the interests, biases and limitations of its creators, and therefore, many civil society organizations have decided not to cooperate with the 'Gateway'. The World Bank 'reply' to these criticisms was the creation of country gateways which are independently owned and operated by partners of the Development nGateway. They operate within a country and each gateway is designed to provide country-level information and resources, and promote local content development and knowledge sharing. They may also be more interactive than the global gateway because of the emphasis on localization in their mandates.

Finally, it is also important to approach the idea of transferring cheap technology and computers to the developing world as a strategy for development. The idea defended by James (2003), among others that shipping in used computers (2-3 years old) to Africa could contribute to development leads to the thought that these destination countries are electronic dumps of the rich countries (in a similar fashion to them already being considered atomic waste dumps by some western corporations). At the same time, why shouldn't these countries enjoy technological progress the same way as western coun tries? Fuchs and Horak (2008) argue that this same rational is behind Negroponte's One Laptop Per Child association and its 100\$ laptop. This computer's technology is inferior to Western standards, with a very slow processor, no hard disk and drives, etc., and hence can be produced and sold rather cheaply. This great difference in technology between western and developing world computers may contribute to an increased global divide. Also, by simply adapting to western technology, or to technology that the West builds specifically for Sub-Saharan Africa, there is the danger of creating a colonial environment driven by ICT (Gebremichael and Jackson, 2006). Perhaps a not so different line of argument and reading of the situation can be established if one looks at the development of Magalhães, a Portuguese-build (based on the Intel Classmate PC) laptop made especially for educational purposes (for school children of grades 1 to 4). At a production cost of 180 euro, and with price ranges from zero to 50 euro (depending on the children's economic background), by spring 2009 about 500,000 units were

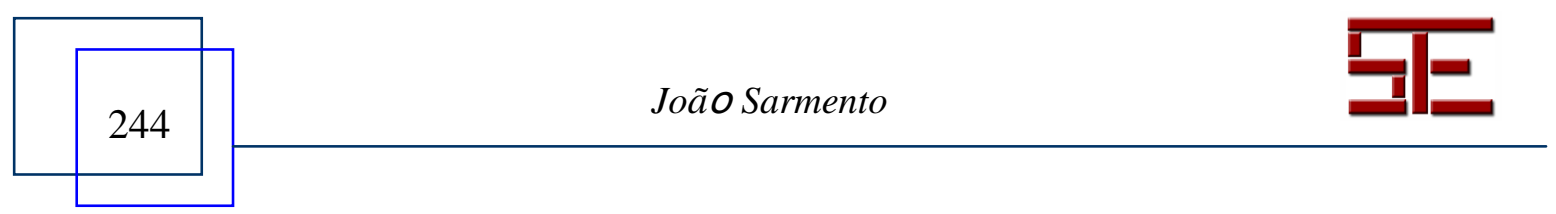




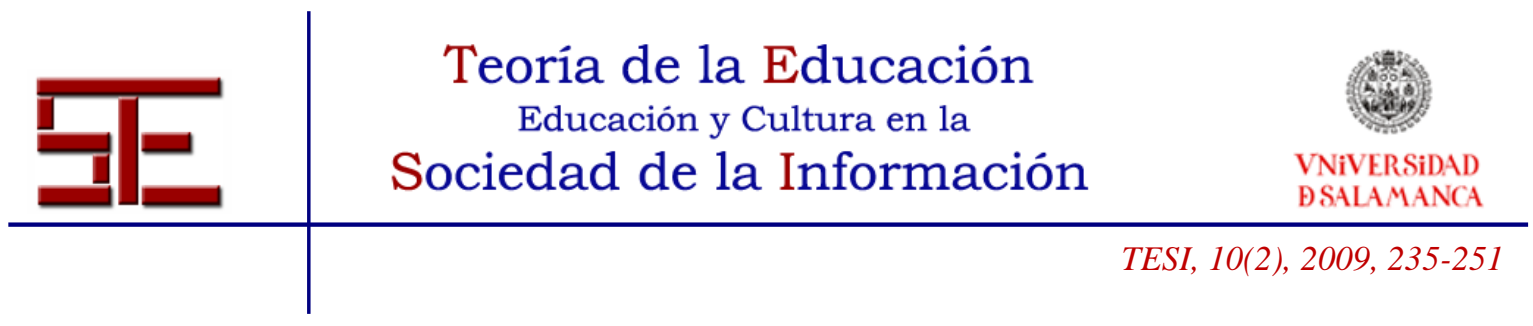

already produced. Symptomatically of its architecture, at the end of 2008 this computer began to be exported and distributed in Venezuela and in early 2009 in Cape Verde.

\section{5.- ON THE GROUND}

There are numerous good practices and success case studies of ICT4D (see Unwin, 2009). HealthNet, a computer-based telecommunication system sponsored by SATELLIFE, a U.S.-based charitable organization dedicated to connecting health professionals around the world, has successful programs in Ethiopia, Mozambique, Ghana, Gambia, the Democratic Republic of the Congo, Tanzania, and Uganda. Other examples of successful ICT development projects in Brazil or Bangladesh for example, geared at addressing real world problems in the developing world weaken the argument that ICT is a luxury that the developing world problems in which we should focus relate to food, shelter, the environment and health.

One of the most visible ICT developments in much of the developing world is the increasing number of telecentres to combat information poverty. The results of experiments with telecentres are mixed: some have demonstrated considerable benefits for their target audiences; others are struggling with fragile connectivity and uncertain communities. Very few have achieved self-financing sustainability (Harris, 2004). In the context of ICT4D and the involvement of African universities, Colle (2005: 102) has argued that 'Universities can become practically involved in ICT by incubating telecentres, which are part of the worldwide ICT4D movement'. Unlike a cybercafé, whose primary mission is profit, a telecentre shares with Universities the fact that they are public facilities in the community, which should provide the opportunity to use computers, networks, copiers, scanners, printed materials, and audio and video resources for information searching, communication and training.

M. S. Swaminathan Research Foundation (MSSRF) is a non-profit Trust established in 1988. As stated on the organisation web site (http://www.mssrf.org/), its aims are to develop a "pro-nature, pro-poor and pro-women orientation to a job-led economic growth strategy in rural areas through harnessing science and technology for environmentally sustainable and socially equitable development'. The Foundation work on seven different areas: Coastal Systems Research, Biodiversity, Biotechnology, Ecotechnology, Food Security, Information, Education and Communication, and Special Projects.

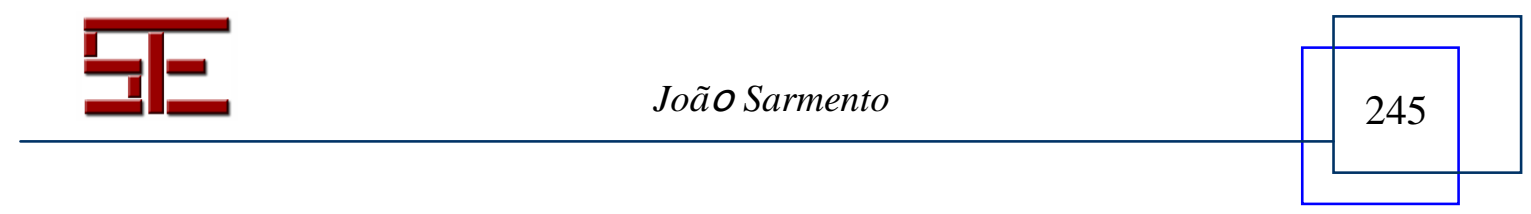




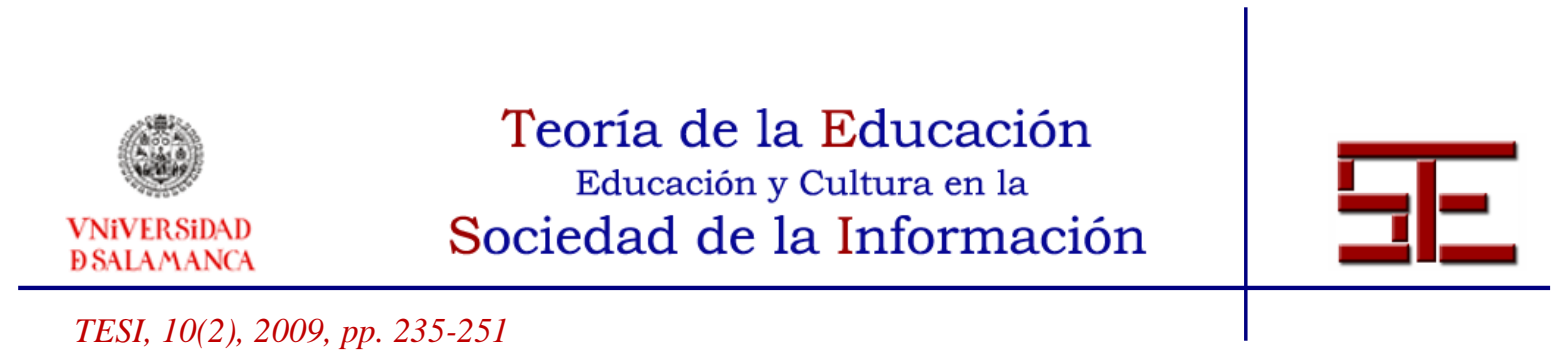

One of the most interesting and perhaps mediatised projects of the MSSRF takes place in the small fishing village of Veerampatinam, south of Pondicherry, in India.

This project started in 2001, and consists of a Village Knowledge Centre (VKC) connected to an IT Hub, which is run by local women who use the Internet for all sorts of activities. Every morning the weather data in the Bay of Bengal is downloaded from the websites of CNN and the US naval weather service, and the height of the waves and the directions of the wind are announced through the village's temple loudspeakers. Mortality rate among the fishermen has been drastically reduced, due to better risk management, and this project is listed by India Today as one among the 57 innovations that have made a difference to the people. It is an excellent example of how high-tech can be combined with low-tech for very good effect.

In fact, Radio, has achieved impressive results in the delivery of useful information to poor people, and one of its strengths is its ubiquity. A survey of 15 hill villages in Nepal found radios in every village, with farmers listening to them while working in the fields. Another survey of 21,000 farmers enrolled in radio-backed farm forums in Zambia found that 90 percent found programmes relevant and more than 50 percent credited the programmes and forums with increasing their crop yields (Dodds, 1999). Other examples coming from the Philippines, illustrates that projects may not only increase local business and agricultural productivity, but also result in the formation of civic organizations and more constructive dialogue with local officials (UNESCO Courier 1997). In Mozambique, the National Institute for Disaster Management distributed Freeplay radios so that flood victims could receive broadcasts on the weather, health issues, government policy toward the displaced, missing family members, the activities of the aid community, and the location of land mines.

In rural Uganda, it is primarily women who provide for households, either by doing most of the farming or starting small local businesses. Despite this role, it is men who usually have access to credit and local business exchanges, while women face many difficulties in starting local businesses, since local cultural practices make them obtain credit through their husbands first. Because they do not have time to network locally in order to sell goods, and they are not taught basic business skills, ICT may offer an effective tool to disseminate information and to allow them to connect. Yet, access to ICT is limited, and the costs of connecting to the Internet are prohibitively high for the typical woman in rural Uganda (see Mwesige, 2004 for an analysis of the cyber elites in Uganda). The Council for Economic Empowerment for Women of Africa (CEEWA)-

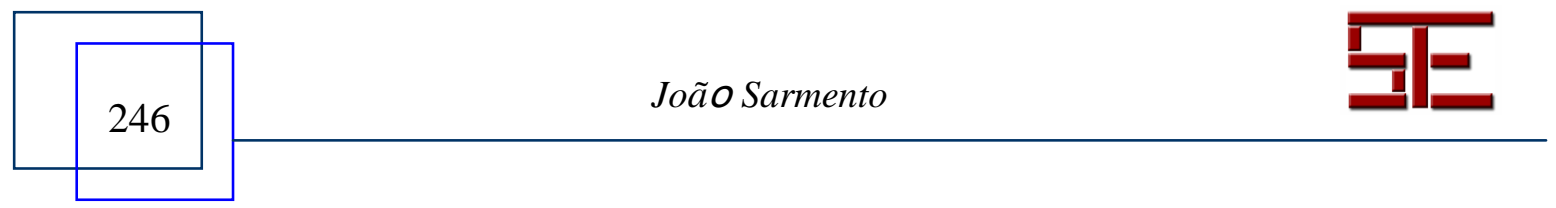




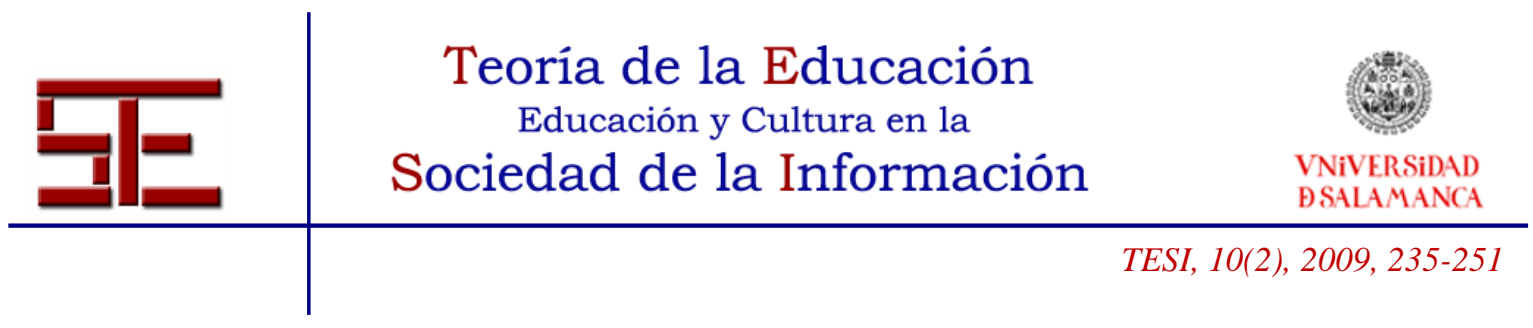

Uganda is a non-governmental and nonprofit organization working to promote the economic empowerment of women in the development process. CEEWA was born at the fifth African NGO Forum held in Dakar, Senegal in 1994, and started its activity in 1995. CEEWA-U developed an ICT Project to 'bridge the information gap between information sources, institutions with information and the end users' (CEEWA-U, 2006). The Project intends to facilitate the articulation between women at the grass root level, and the impact of government policies and programmes.

At an earlier stage, and with the financial support from the International Development Research Centre (1999-2001), CEEWA-U was able to mobilize women and run a pilot test of the Project in three districts: Mpigi, Wakiso and Kampala, in central Uganda.

The aim of this project was to create awareness among women entrepreneurs about the role of ICTs in empowering and strengthening their ability to run and manage their lives and businesses. Later on, with the support of the Humanistic Institute for Cooperation with Developing Countries (Hivos), the project continued in six districts/sites. The project has several components. Here I would like to highlight the four that seem to me to be more relevant in the present discussion.

The first one concerns the Women Information Resource Electronic Service (WIRES), which allows rural entrepreneur women and women organisations to update access information on market prices, advisory services, trade support services, business and entrepreneurship tips, best practices in Agriculture among other relevant information to the development of their enterprises (this database driven website can be found at www.ceewauganda.org). The second is the Empowerment Resource Centre (ERC) which aims at providing women and the general public with necessary skills for effective career development and business management. The ERC is a one-stop centre that provides services to women, youth and the public. The services include empowerment sessions, print library, training in entrepreneurship development, business management skills and Consultancy, computer training, Internet access, and secretarial services among others. A third dimension of the project is the ICT project Partnership with the Communities in which CEEWA-U works closely with the existent community telecentres of Nabweru and Buwama in central Uganda, as a means to reach the communities. The telecentres are used for ICT training and disseminating information. A final aspect of CEEWA-U is the Mukono Information and Communication Centre, a business centre which was created to replicate the services of the already established community telecentres and to attempt to demystify ICTs among rural communities. The centre is currently fully operational offering training in ICTs

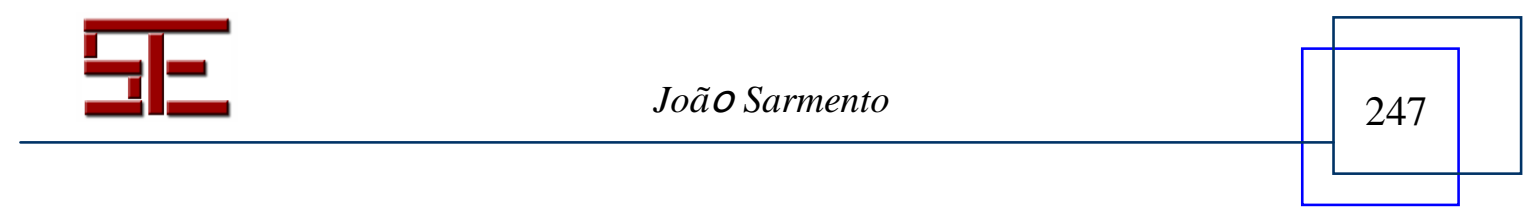




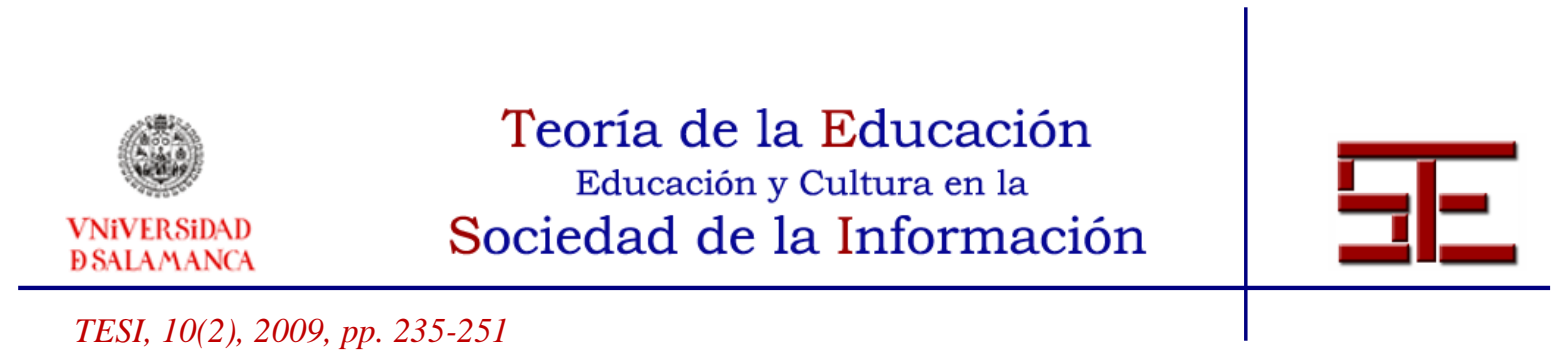

and their application in business, business counselling, telephone services, document processing, computer training and photocopying services among others.

So far the project has mobilized and trained a total of 809 women and men in ICT use and application in business, entrepreneurship development and business management skills. This has raised the awareness on the application and use of ICTs and entrepreneurship development among women entrepreneurs. The project has also developed manuals for training and audiovisual material on ICTs use and application in entrepreneurship in local dialect (Luganda), which has greatly helped women in understanding how different ICT tools can be used and applied in business. Video documentaries on best practices in banana farming, pig farming and poultry keeping have been produced, as well as Booklets on best practices in agriculture, both in English and local language, and are being used by the women entrepreneurs.

This experience shows that ICTs are able to provide women with opportunities for expansion of their economic enterprises as well as for positive social, political and cultural change. There is now a plan to expand the WIRES programme and to create additional telecentres primarily in rural areas. As a result of the demand of ICT training by men, the programme will also finance men's training in the community. In addition, CEEWA-Uganda wants to expand its programme to show women how to use ICT in their daily lives as well as their businesses.

\section{6.- FINAL REMARKS}

Much of the evidence in support of the use of ICTs for alleviating poverty remains anecdotal and the difficulties of measuring the impact of these initiatives should not be underestimated. On the one hand, initiatives are taking place with little reference to each other, leaving a need for field practitioners to take into account the experience that has so far been accumulated. On the other hand, the use of ICTs for poverty alleviation has not achieved the status of a mass movement and there are considerable challenges in turning a promising experiment into a mass use. ICT implementation in developing countries cannot ignore critical institutional barriers such as poverty, poor access, deficient infrastructure support and servicing, low literacy levels, electricity problems, and high costs of subscription to Internet Service Providers. Yet, many of the existing success stories illustrate that the main challenges are not actually in the technology itself, but in the organisation, coordination and establishment of a motivational and creative environment among various stakeholders and people.

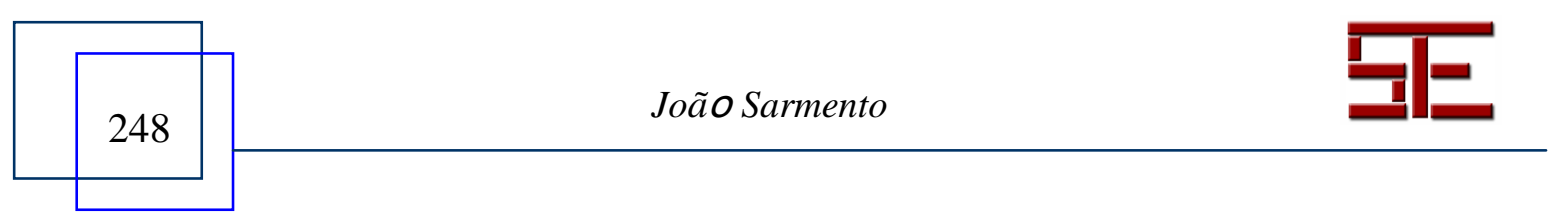




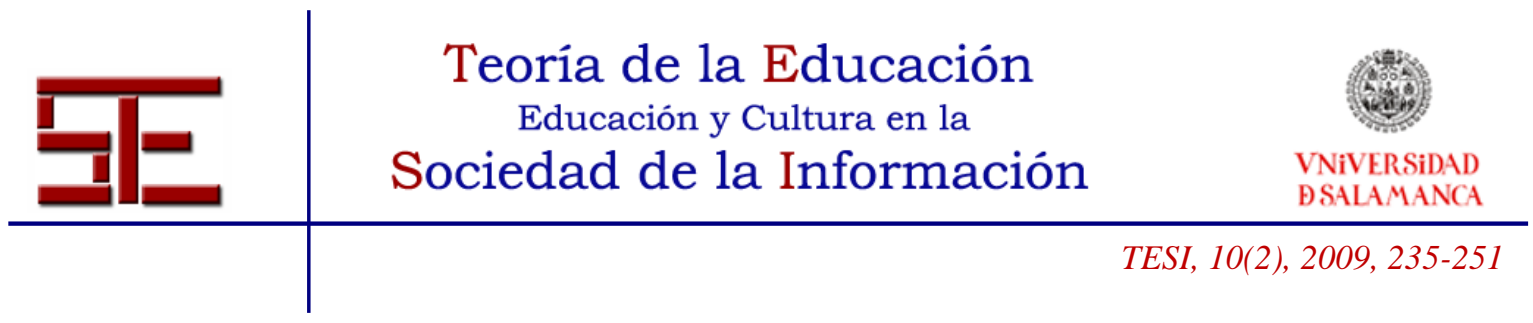

\section{BIBLIOGRAPHY}

Annan, K. (2002). 'Kofi Annan's IT challenge to Silicon Valley' CNET [accessed on June 2008: http://news.com.com/2010-1069-964507.html].

Beck, U. (2006). Power in the global age. Cambridge, Polity.

Bridges.org (2005). Freelopen source software (FOSS) policy in Africa: A toolkit for policy-makers and practitioners; Component 2A on open source software and low-cost computing under the Catalysing Access to ICTs in Africa (CATIA) programme; South Africa [www.bridges.org, accessed 9.11.2006].

Castells, M. (1996-98). The Information Age. Economy, Society and Culture. 3 Vols. Oxford, Blackwell.

Castells, M. (2002). The Internet Galaxy. Oxford University Press, Oxford.

Colle, R. D. (2005). Building ICT4D capacity in and by African universities, International Journal of Education and Development using Information and Communication Technology, 1(I), 101-107.

Dodds, T. (1999). Non-Formal and Adult Basic Education Through Open and Distance Learning in Africa Centre for External Studies, Namibia, University of Namibia.

European Commission (2001). The Role of ICTs in EC Development Policy, Brussels, European Commission.

Fuchs, C. y Horak, E. (2008). Africa and the digital divide Telematics and Informatics, 25(2), 99-116.

Gebremichael, M. D. y Jackson, J. W. (2006). Bridging the gap in Sub- Saharan Africa: A holistic look at information poverty and the region's digital divide, Government Information Quarterly; 23; pp. 267-280.

Harris, R. W. (2004). Information and Communication Technologies for poverty alleviation. Kuala Lumpur, UNDP-APID.

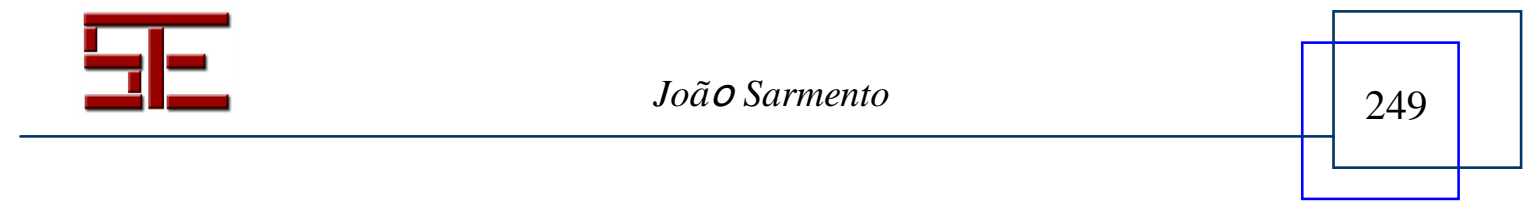




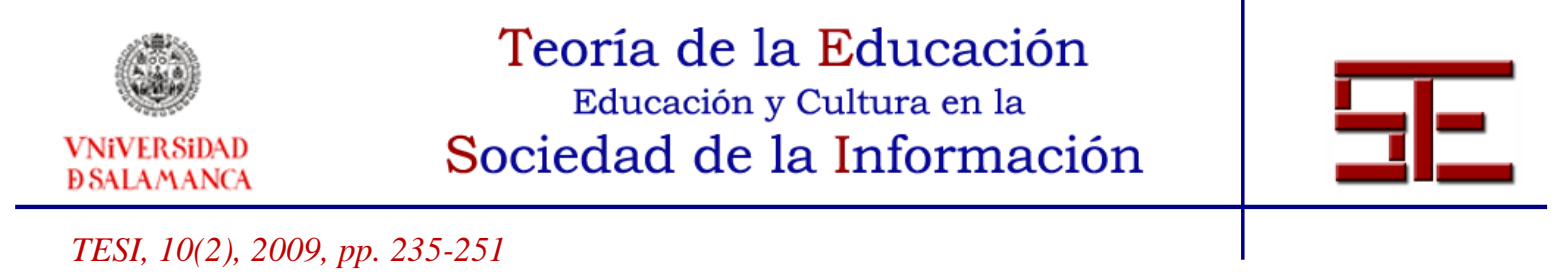

ITU (2006). World Information Society Report. Geneva, International Communication Union.

James, J. (2003). Bridging the Global Digital Divide. Cheltenham, Edward Elgar.

Limb, P. (2006). The Digitalisation of Africa, Africa Today 52(2), January, 3-19.

Mwesige, P. G. (2004). Cyber elites: a survey of Internet Café users in Uganda, Telematics and Informatics 21, 83-101.

Negroponte, N. P. (1995). Being Digital. New York, First Vintage Books.

Sarmento, J. (2004). Representação, Imaginação e Espaço Virtual: Geografias de Paisagens Turísticas dos Açores e de West Cork. Lisbon, Fundação para a Ciência e Tecnologia e Fundação Calouste Gulbenkian.

UNDP (1999). New Technologies and the Global Race for Knowledge, in Human Development Report. New York, United Nations Development Program.

United Nations (2005). Strengthening the capacity of national machineries through the effective use of ICT, in UN (eds.) Economic and Social Commission for Western Asia (ESCWA). Beirut, Unesco.

United Nations (2006). The Millennium Development Goals Report 2006. New York, United Nations.

Unwin, T. (2009). (ed.) ICT4D: Information and Communication Technology for Development. Cambridge, Cambridge University Press.

Van dijk, J. A. y G. M. (2006). Digital divide research, achievements and shortcomings, Poetics, 34; 221-235.

Van Dijk, J. y Hacker, K. (2003). The digital divide as a complex, dynamic phenomenon, The Information Society 19 (4), 315-326.

World Bank (2002). Information and Communication Technology Sector Strategy Paper. April. Washington, World Bank.

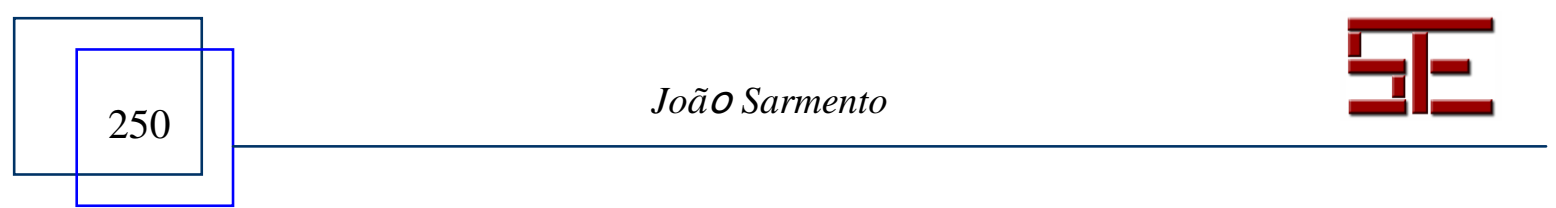




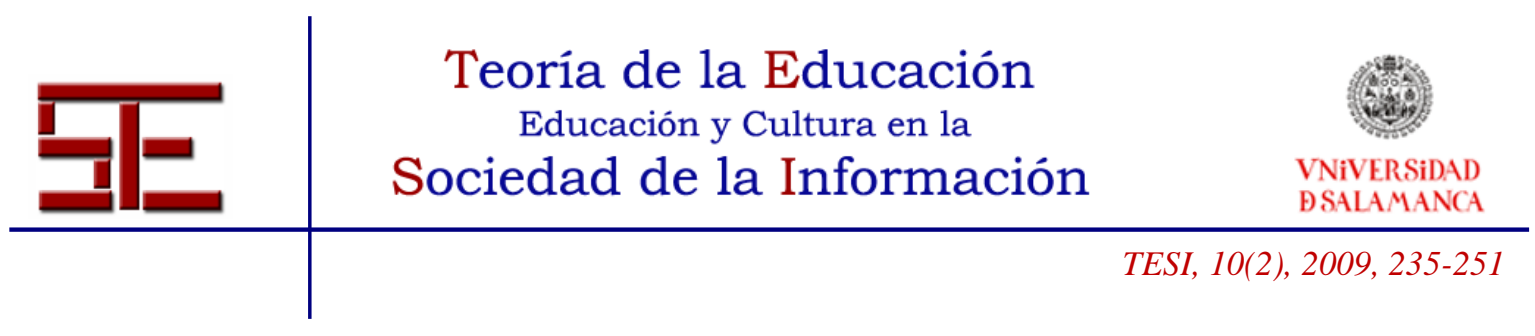

\begin{abstract}
Notas
1 An earlier version of this paper was published with the title 'ICT4D: How do we build a Second Digital Revolution?' in Chimera 23, University College Cork Geographical Journal, Cork, Ireland, pp.83-96. 2 The European Commission suggests that poverty should not be defined merely as a lack of income and financial resources, and should include the deprivation of basic capabilities and lack of access to education, health, natural resources, employment, land and credit, political participation, services, and infrastructure (European Commission, 2001).

3 Set out in 2000 as part of the United Nations Millennium Declaration and adopted by 189 nations and signed by 147 heads of state and governments, the Millennium Development Goals are to Eradicate extreme poverty \& hunger; Achieve universal primary education; Promote gender equality and empower women; Reduce child mortality; Improve maternal health; Combat HIV/AIDS, malaria \& other diseases; Ensure environmental sustainability; Develop a global partnership for development.

4 The political importance of the Geneva meeting can be illustrated by the presence of 50 Heads of state/government and Vice-Presidents, 82 Ministers and 26 Vice-Ministers, Heads of delegation from 175 countries and high-level representatives from international organizations, private sector, and civil society. There were more than 11,000 participants from 175 countries.

5 Financial mechanism of a voluntary nature, open to interested stakeholders focusing mainly on specific and urgent needs at the local level, and seeking new voluntary sources of "solidarity" finance. The DSF complements existing mechanisms for funding the Information Society.
\end{abstract}

Para citar la presente editorial puede utilizar la siguiente referencia:

Sarmento, J. (2009). Information and comunication technologies for development: examples from India and Uganda, en Ortega Sánchez, I. y Ferrás Sexto, C. (Coord.) Alfabetización Tecnológica y desarrollo regional. Revista Electrónica Teoría de la Educación: Educación y Cultura en la Sociedad de la Información. Vol. 10, no 2. Universidad de Salamanca, pp. 235-251 [Fecha de consulta: dd/mm/aaaa]. http://campus.usal.es/ revistas_trabajo/index.php/revistatesi/article/view/7515/7547

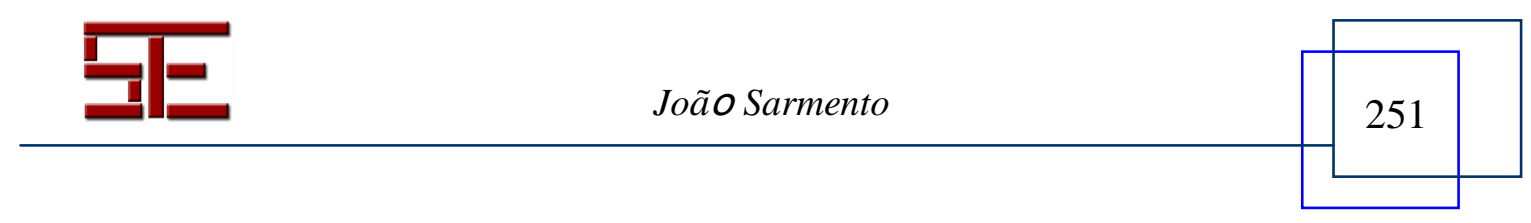

